\title{
Cambios y continuidades en el valle de Lurín a la llegada de los incas: el caso de Pampa de Flores
}

Changements et continuités dans la vallée de Lurín à l'arrivée des Incas : le cas de Pampa de Flores

Change and continuity in the Lurin Valley with the arrival of the Incas: the case of Pampa de Flores

\section{Camila Capriata Estrada y Raúl Zambrano Anaya}

\section{OpenEdition}

\section{Journals}

Edición electrónica

URL: http://journals.openedition.org/bifea/8492

DOI: $10.4000 /$ bifea.8492

ISSN: 2076-5827

\section{Editor}

Institut Français d'Études Andines

\section{Edición impresa}

Fecha de publicación: 1 agosto 2017

Paginación: 377-399

ISSN: 0303-7495

\section{Referencia electrónica}

Camila Capriata Estrada y Raúl Zambrano Anaya, "Cambios y continuidades en el valle de Lurín a la llegada de los incas: el caso de Pampa de Flores », Bulletin de l'Institut français d'études andines [En línea], 46 (2) | 2017, Publicado el 08 agosto 2017, consultado el 10 diciembre 2020. URL : http:// journals.openedition.org/bifea/8492 ; DOI : https://doi.org/10.4000/bifea.8492

\section{(c) $(1) \odot$}

Les contenus du Bulletin de l'Institut français d'études andines sont mis à disposition selon les termes de la licence Creative Commons Attribution - Pas d'Utilisation Commerciale - Pas de Modification 4.0 International. 


\title{
Cambios y continuidades en el valle de Lurín a la llegada de los incas: el caso de Pampa de Flores
}

\author{
Camila Capriata Estrada* \\ Raúl Zambrano Anaya**
}

\section{Resumen}

Esta investigación explora la continuidad, transformación y cambios ocurridos en la arquitectura monumental del Periodo Intermedio Tardío en las comunidades del valle de Lurín a la llegada de los incas, y sus implicancias en su organización social y política. Se pone especial énfasis en el sitio arqueológico de Pampa de Flores, ubicado a pocos kilómetros del litoral, el cual constituye el segundo asentamiento más grande del valle, luego de Pachacamac.

Palabras clave: incas, arquitectura monumental, valle de Lurín, Ychsma

\section{Changements et continuités dans la vallée de Lurín à l'arrivée des Incas : le cas de Pampa de Flores}

\section{Résumé}

Cette recherche explore la continuité, la transformation et les changements survenus dans l'architecture monumentale de la Période Intermédiaire Récente dans les communautés de la vallée du Lurin à partir

* Directora del Proyecto de Tramo Xauxa-Pachacamac, Qhapaq Ñan-Sede Nacional, Ministerio de Cultura del Perú, Av. Javier Prado Este 2465, San Borja - Lima 41, Perú. E-mail: ccapriata@cultura. gob.pe

** Arqueólogo Investigador del Proyecto de Tramo Xauxa-Pachacamac Qhapaq Ñan-Sede Nacional, Ministerio de Cultura del Perú, Av. Javier Prado Este 2465, San Borja - Lima 41, Perú. E-mail: rzambrano@cultura.gob.pe 
de l'arrivée des Incas, et leurs conséquences dans l'organisation sociale et politique. L'accent est mis sur le site archéologique de Pampa de Flores, situé à quelques kilomètres du littoral, et qui constitue la deuxième plus grande occupation de la vallée après Pachacamac.

Mots-clés : Incas, architecture monumentale, Vallée de Lurín, Ychsma

\title{
Change and continuity in the Lurin Valley with the arrival of the Incas: the case of Pampa de Flores
}

\begin{abstract}
This research explores the continuity, transformation and changes that occurred in the Late Intermediate Period monumental architecture of the Lurin Valley with the arrival of the Incas, and the consequences that had on its social and political organization. Special emphasis is given to the archaeological site of Pampa de Flores, located a few kilometers from the coast-line, and that constitutes the second largest settlement in the valley after Pachacamac.
\end{abstract}

Key words: Incas, monumental architecture, Lurin valley, Ychsma

\section{INTRODUCCIÓN}

En años recientes, diversos proyectos han centrado sus investigaciones en el valle de Lurín, especialmente en asentamientos ocupados entre el Intermedio Tardío (ca 900-1470 d. C.) y el Horizonte Tardío (ca 1470-1533 d. C.). Estos trabajos han sido complementados con el estudio de un tramo del Qhapaq Ñan que recorre este valle y de su importancia como eje articulador entre estos asentamientos. Esta investigación forma parte de un proyecto para la gestión del tramo XauxaPachacamac, en el que los autores vienen trabajando, como parte del Qhapaq Ñan-Sede Nacional del Ministerio de Cultura.

Durante el Intermedio Tardío, el valle de Lurín fue ocupado por poblaciones vinculadas al Señorío de Ychsma (Eeckhout, 2004; Rostworowski, 1978). La conquista de la costa central por parte de los incas habría producido cambios a nivel social, político y religioso al interior de estas comunidades (López-Hurtado, 2011; Marcone, 2004). En el caso de Pachacamac estos cambios fueron radicales, e implicaron una transformación del espacio, no solo física, sino también religiosa, ya que la presencia inca dio pase al resurgimiento del santuario y a la expansión de este culto (Eeckhout, 2003a; 2003b; López-Hurtado \& Nesbitt, 2010). En otros asentamientos del valle, estos cambios se habrían manifestado en menor escala (Capriata \& López-Hurtado, 2017).

En este artículo exploramos el impacto de la conquista inca sobre las comunidades locales. Proponemos que los cambios políticos y las variaciones en el orden jerárquico dentro del sistema de asentamientos del valle habrían sido producto de las diferentes estrategias de control que los incas impusieron sobre las poblaciones locales: ya sea a través de alianzas con las elites o de la toma del poder sobre 
ellas. Para ello, nos centraremos en el valle bajo, y analizatrmos la continuidad, transformación y cambios en el uso de edificios públicos como reflejo de estas estrategias de control político. Tomaremos como referencia central el caso del asentamiento de Pampa de Flores, ubicado a pocos kilómetros de Pachacamac.

\section{CONTEXTO GEOGRÁFICO}

El río Lurín pertenece a la vertiente del Pacífico y se origina en los Andes centrales, teniendo un recorrido transversal de este a oeste, bajando desde las alturas de Huarochirí, hasta su desembocadura junto al Santuario de Pachacamac. En el marco de esta investigación, nos centraremos en la ocupación del área geográfica denominada «valle bajo», definida de acuerdo a lo planteado por Marcone y López-Hurtado (Marcone, 2004; Marcone \& López-Hurtado, 2002) con base en la propuesta de Earle (1972). De acuerdo con los autores, esta región abarcaría, de oeste a este, dos grandes zonas: una primera comprendida entre el litoral y la localidad actual de Tambo Inga, zona asentada sobre el cono de deyección del valle; una segunda ubicada entre este asentamiento y los sitios arqueológicos de Lindero y Chontay, caracterizada por la presencia de quebradas dentro de la zona denominada «chaupi yunga». A partir de este punto, siguiendo el curso del río hacia el este, el valle se estrecha y se encañona. Si bien los autores proponen que el valle bajo se extienda hasta Avillay, para propósitos de esta investigación solo abarcaremos el área señalada.

La división geográfica propuesta, es decir las dos primeras secciones del valle bajo, parece correlacionarse con una división de carácter cultural. Existe una evidente similitud en ciertos patrones, tanto en la ubicación de los asentamientos como en sus características arquitectónicas. A excepción de Pachacamac, la mayor parte de los sitios referidos en este artículo se ubican en quebradas secas en ambas márgenes del río, separadas por distancias de entre uno y cinco kilómetros. Este es el caso de los asentamientos de Pampa de Flores, Quebrada Golondrina, Tijerales, Villa Toledo (o Colca), Panquilma, Molle, Huaycán de Cieneguilla, Río seco y Chontay (fig. 1). Todos ellos son, además, asentamientos multicomponentes que comparten un patrón arquitectónico caracterizado por la presencia de recintos ortogonales aglutinados, hechos con muros de piedra y mortero de barro, con enlucidos también en barro, y muchas veces pintados en colores rojo y amarillo. Estas estructuras generalmente se pueden agrupar en conglomerados debido a la presencia de muros perimétricos que los separan distintivamente. Casi todos los asentamientos tienen áreas públicas como patios o plazas; algunos presentan arquitectura monumental. Una característica particular de asentamientos como Pampa de Flores, Tijerales, Panquilma, Huaycán, Molle, Río Seco y Chontay, es la presencia de muros con frisos en bajo relieve, ubicados en patios o recintos. 


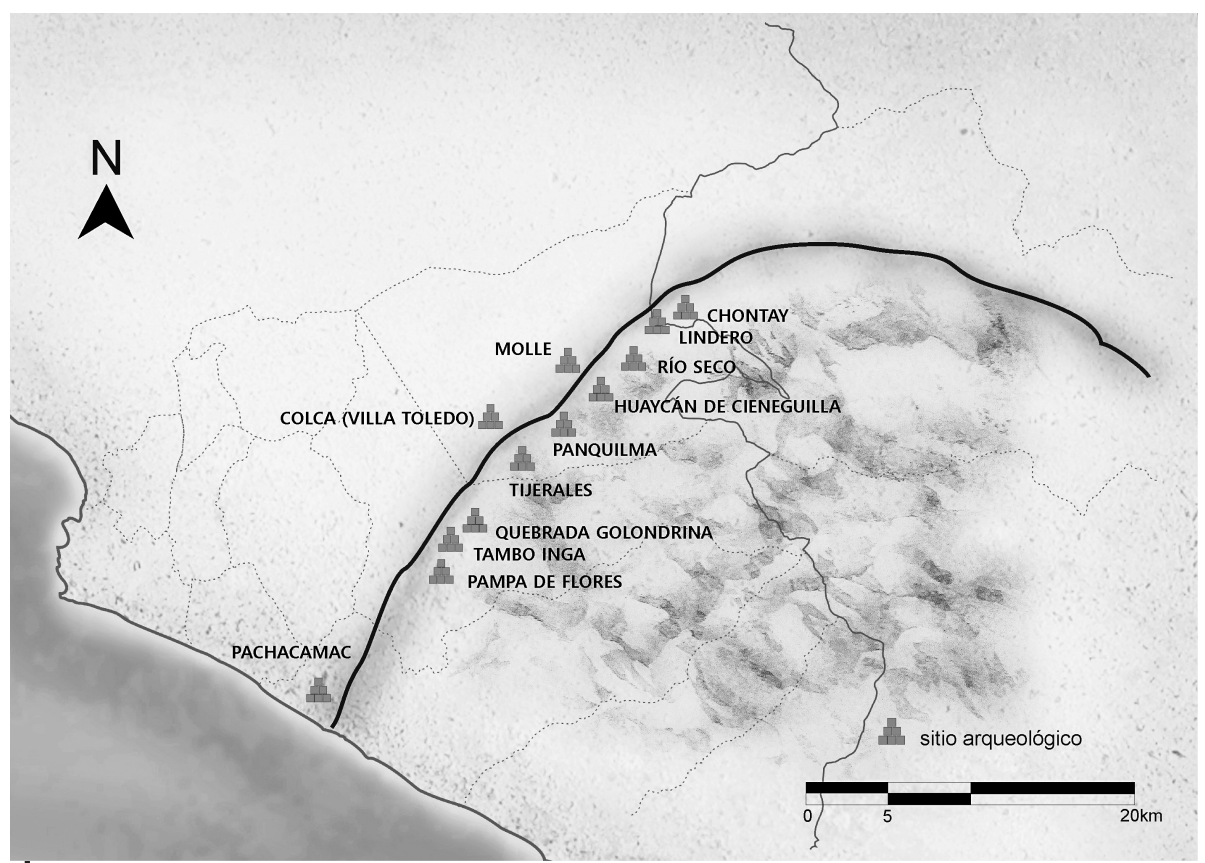

Figura 1 - Ubicación de sitios arqueológicos tardíos en el valle de Lurín

(c) Proyecto Qhapaq Ñan

\section{EL VALLE DE LURÍN EN LOS PERIODOS TARDÍOS}

En el Intermedio Tardío, el valle bajo del río Lurín estuvo habitado por poblaciones ligadas al Señorío de Ychsma, una confederación cuya vinculación se habría centrado en el culto a Pachacamac (Bazán, 1990; Feltham, 1983; Marcone, 2004; Rostworowski, 1972; 2002; 2004). Recientes estudios sugieren además la presencia de al menos dos grupos yungas en la parte baja del valle durante este periodo, aunque aún no quedan claras las implicancias políticas y culturales de esta subdivisión (Eeckhout 2008; Zambrano, 2016).

El paisaje arquitectónico se caracterizó por la construcción de una serie de edificaciones monumentales denominadas «Pirámides con Rampa», identificadas en diferentes asentamientos a lo largo del valle (Bueno, 1983; Eeckhout, 1995; Franco, 1993; Jiménez Borja \& Bueno, 1970; Paredes Botoni, 1988; Paredes Botoni \& Franco, 1987; Uhle, 1903). Si bien estos asentamientos habrían estado afiliados a este señorío, recientes investigaciones sugieren que se habría tratado de organizaciones políticas independientes, administradas por elites locales (LópezHurtado, 2011).

Eeckhout menciona la presencia de al menos 43 Pirámides con Rampa (de ahora en adelante PCR) en el valle, de las cuales la mayor parte se ubican en Pachacamac y Pampa de Flores, ambos sitios ubicados en la parte más baja (Eeckhout, 2003a: 
149). El autor registra la presencia de estos edificios también en Panquilma y Tijerales. Con base en nuestros trabajos, hemos podido también registrar al menos dos PCR en Villa Toledo (Colca), además de un edificio con características similares en Quebrada Golondrina.

Hasta la fecha solo se cuenta con fechados radiocarbónicos para Pachacamac, en donde la mayor parte de pirámides habrían sido construidas a lo largo del Intermedio Tardío (Eeckhout, 2010; Michczynski et al., 2003). Según Eeckhout, muchas muestran evidencias de reutilización durante el Horizonte Tardío, aunque el uso posterior se restringe a ocupaciones domésticas temporales, actividad ritual y ocupaciones funerarias (Eeckhout, 2010). Makowski ha propuesto que algunas de las pirámides de Pachacamac podrían haber sido construidas durante el Horizonte Tardío, debido a su disposición y a los accesos desde la calle NorteSur (Makowski et al., 2005).

En términos generales, las PCR se componen de plataformas superpuestas conectadas por una rampa, tienen una plaza central en la parte inferior y suelen tener una serie de recintos asociados que forman parte del volumen principal de la estructura (Eeckhout, 2003a: 141; Farfán, 2004: 452). Algunas diferencias en el tamaño y la configuración espacial de las partes que las componen han llevado a los investigadores a proponer distintas interpretaciones sobre su posible función (ver discusión en: Bueno, 1983; Eeckhout, 2000; 2003a; Jiménez Borja, 1992; López-Hurtado, 2011). En un análisis exhaustivo sobre las características de las PCR, Eeckhout (2003a) identifica tres tipos de edificio de acuerdo a la posición de la rampa: Tipo A, con una rampa lateral ubicada a un lado del atrio, Tipo B, con una rampa central perpendicular al atrio y Tipo $\mathrm{C}$, con una rampa central paralela al atrio. El autor propone, en resumen, que las del Tipo $\mathrm{C}$ habrían sido usadas como residencias de elite en donde se realizaban festines con gran afluencia de público, mientras que las de los otros dos tipos habrían cumplido funciones rituales con una afluencia menor de público. Agrega también que el Tipo $C$ es el más común, si bien aparece casi exclusivamente en Pachacamac y Pampa de Flores; relaciona este factor a la importancia de ambos sitios como centros Ychsma dentro de una organización «dual» en el valle.

Las diferencias, entonces, estarían también relacionadas con la organización política del valle. Ciertamente la semejanza entre los edificios de Pachacamac y Pampa de Flores, así como su cantidad presente en cada sitio, coloca al segundo en una posición diferenciada respecto a los otros asentamientos del valle. Un dato adicional es que las PCR se concentran en la parte más baja del valle. Todos los edificios registrados se encuentran entre el litoral y Panquilma. Valle arriba, los edificios públicos registrados corresponden a las denominadas «audiencias», patios cerrados con plataformas contiguas conectadas a través de rampas. Estas edificaciones fueron construidas hasta la zona de Chontay. Esta diferenciación en el tipo de edificios públicos, sumada a otros factores como la presencia de

1 Los autores consideran que el edificio con rampa ubicado en Huaycán de Cieneguilla no corresponde a una PCR. 
frisos asociados a las audiencias y el patrón funerario, podría ser representativa de la identidad de diferentes grupos conviviendo en el valle y que, a la vez, compartían rasgos culturales expresados en el material cerámico y textil, entre otros (Zambrano, 2016).

Por otro lado, Villacorta describe una serie de edificios con similares características a las PCR y a las audiencias para el valle medio del Rímac (Villacorta, 2004). Estos edificios, sin embargo, son menos imponentes que aquellos registrados en Pachacamac, como también sucede en el resto del valle de Lurín; en su diseño se excluyen algunos componentes como los grandes depósitos asociados y los espacios de uso residencial. Villacorta considera que estas variaciones se «explicarían a partir de las posibilidades sociales y económicas de sus promotores (p.e. disposición de la mano de obra, uso de excedentes, etc.), como a restricciones derivadas del sistema político o religioso acordadas, impuestas y toleradas por Pachacamac». (Villacorta, 2004: 550).

Las recientes investigaciones desarrolladas en Pampa de Flores (Capriata, 2014; Capriata et al., 2014) y Panquilma (Capriata \& López-Hurtado, 2017; LópezHurtado, 2010; 2011; López-Hurtado et al., 2014) apoyan el modelo propuesto por Eeckhout quien sugiere que las pirámides fueron usadas como palacios y/o residencias de elite (Eeckhout, 2003a; 2003b). En el caso particular de Panquilma, sin embargo, no queda claro el uso de las PCR como lugar de veneración a los ancestros. En efecto, las plazas parecen haber sido usadas para rituales como lo demuestra la evidencia de entierros de ofrendas asociados a los diferentes momentos de uso de este espacio (López-Hurtado, 2011; López-Hurtado et al., 2014). No obstante, los únicos entierros encontrados por López-Hurtado en las PCR corresponden a entierros múltiples de individuos, probablemente secundarios, sin mayor tratamiento, hallados al interior de depósitos.

En general, las plazas de todas las PCR habrían servido como espacios de interacción con grupos selectos ante los cuales se realizaban actividades de elite como banquetes o ceremonias. Estas edificaciones cumplieron además un importante rol en la economía local ya que, como señala Eeckhout, estuvieron «frecuentemente equipadas de tendales y depósitos para almacenar productos probablemente fruto de algún tipo de tributo» (2004: 406). En complemento, el autor propone que no todos los edificios al interior de un asentamiento se habrían utilizado de forma simultánea, ya que habría habido una sucesión de tipo dinástica entre sus ocupantes, sugiriendo el abandono o cierre ritual de la estructura posterior a la muerte de su ocupante principal (Eeckhout, 2003b; 2010; Michczynski et al., 2003).

La arquitectura monumental de la costa central sufrió distintas transformaciones a través de la época prehispánica. Es así que, como lo señala Villacorta, durante el Horizonte Medio se dejaron de construir edificios de gran tamaño como los del complejo Maranga o de la Huaca Pucllana (Villacorta, 2004). La tradición de las PCR, así como de los palacios del valle del Rímac, habría surgido durante el Intermedio Tardío y, como lo veremos más adelante, continuado hasta el Horizonte Tardío. 
En general, a diferencia de Pachacamac, los asentamientos del valle de Lurín durante el Horizonte Tardío se caracterizaron por la ausencia de elementos arquitectónicos típicos incas tales como los accesos y ventanas trapezoidales, las puertas de doble jamba o el uso de piedras finamente labradas. La única excepción la constituiría Huaycán de Cieneguilla, en donde sí se ha podido apreciar la presencia de algunas de estas características, aunque el patrón constructivo sigue siendo esencialmente local (Marcone, 2004: 728).

\section{PAMPA DE FLORES}

Durante los años 2013 y 2014, realizamos excavaciones en el sitio arqueológico de Pampa de Flores como parte de los trabajos desarrollados por el Qhapaq NanSede Nacional. Se trata del segundo mayor asentamiento en el valle y se articula con el resto de sitios a través del tramo de camino que unía Pachacamac con el centro administrativo inca de Hatun Xauxa. El sitio, que data del Intermedio Tardío, está ubicado en la margen izquierda del río Lurín, a aproximadamente 14 kilómetros al sureste de Pachacamac. Tiene una extensión de 19 hectáreas (área construida sobre dos quebradas) y se compone de 4 sectores: el Sector 1 , con 13 PCR y una serie de complejos habitacionales, el Sector 2, compuesto por grandes terrazas de secado, el Sector 3 que es el área de cementerio asociado al asentamiento y, finalmente, el Sector 4, ubicado en una quebrada al sur y que se compone de una PCR y de complejos habitacionales.

A la fecha se han excavado unidades en ocho de las 14 PCR registradas en Pampa de Flores, 7 de ellas en el Sector 1 (fig. 2). Las primeras excavaciones fueron realizadas por Eeckhout en la PCR 3 (Eeckhout, 1998). Posteriormente Jalh Dulanto excavó en las PCR 4 y 52 (2002). Finalmente, durante nuestra investigación excavamos en las PCR 8, 9, 10 y 12 en el Sector 1, además de una pequeña unidad en la PCR 11 ubicada en el Sector 4.

Parte de nuestros trabajos en el sitio se centraron en completar el levantamiento planimétrico iniciado por Peter Eeckhout durante sus excavaciones en la década de 1990, obteniendo de esta forma nueva información referente a la configuración arquitectónica y espacial del asentamiento. En primer lugar fue posible redefinir la presencia y distribución de PCR en el sitio. La información del plano fue complementada con aquella obtenida mediante la excavación de dos unidades colindantes en la sección central superior de un gran espacio rectangular ubicado al oeste de la PCR 9, la cual permitió identificar plataformas unidas mediante una rampa. De acuerdo a los componentes antes mencionados que conforman este tipo de edificio, se estableció que esta rampa pertenecía a una pirámide que no había sido identificada previamente (PCR 12) (fig. 3). El mal estado de conservación

2 De acuerdo a la nomenclatura utilizada para numerar las PCR en nuestro estudio y que se basa en aquella establecida por Eeckhout durante sus excavaciones. Dulanto utiliza una numeración diferente: la PCR que él denomina 5 es para nosotros la PCR 4, y la PCR 6 es para nosotros la PCR 5. 


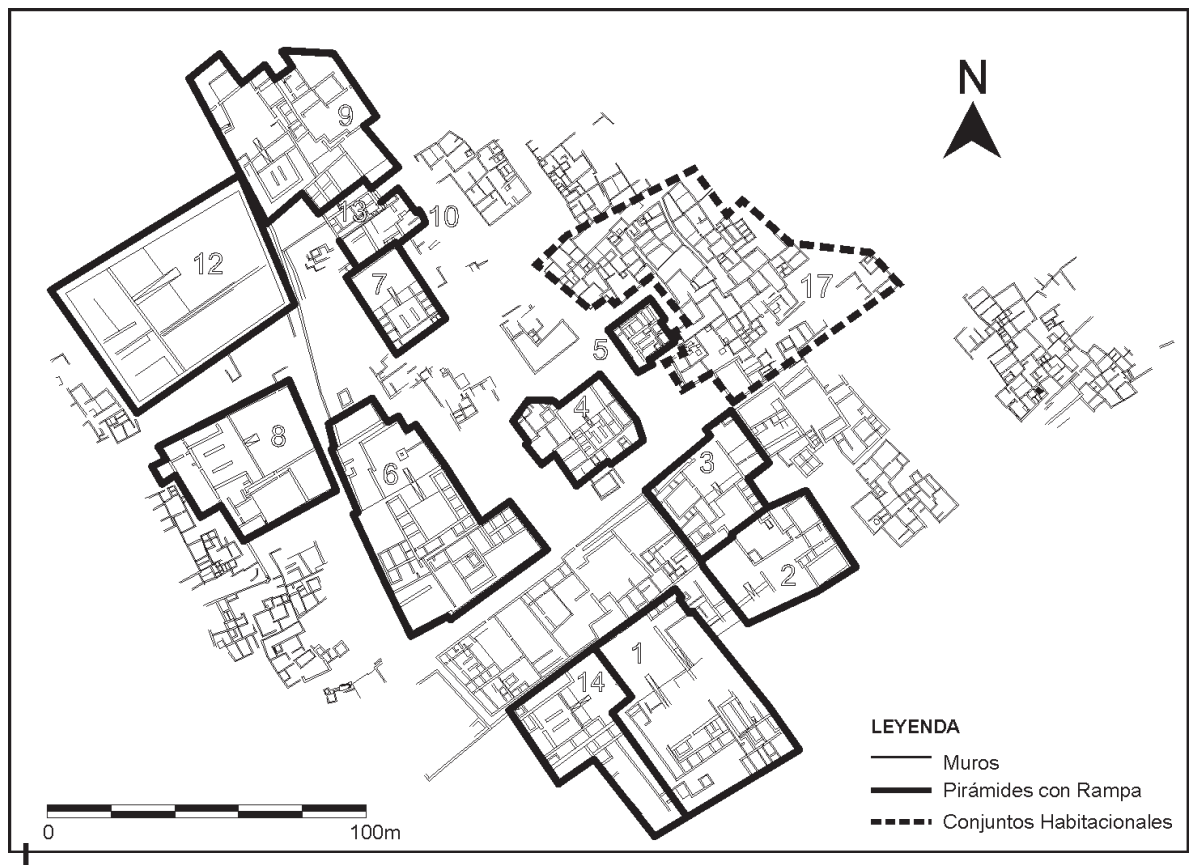

Figura 2 - Plano del Sector 1 de Pampa de Flores

Plano elaborado por Alexis Solís

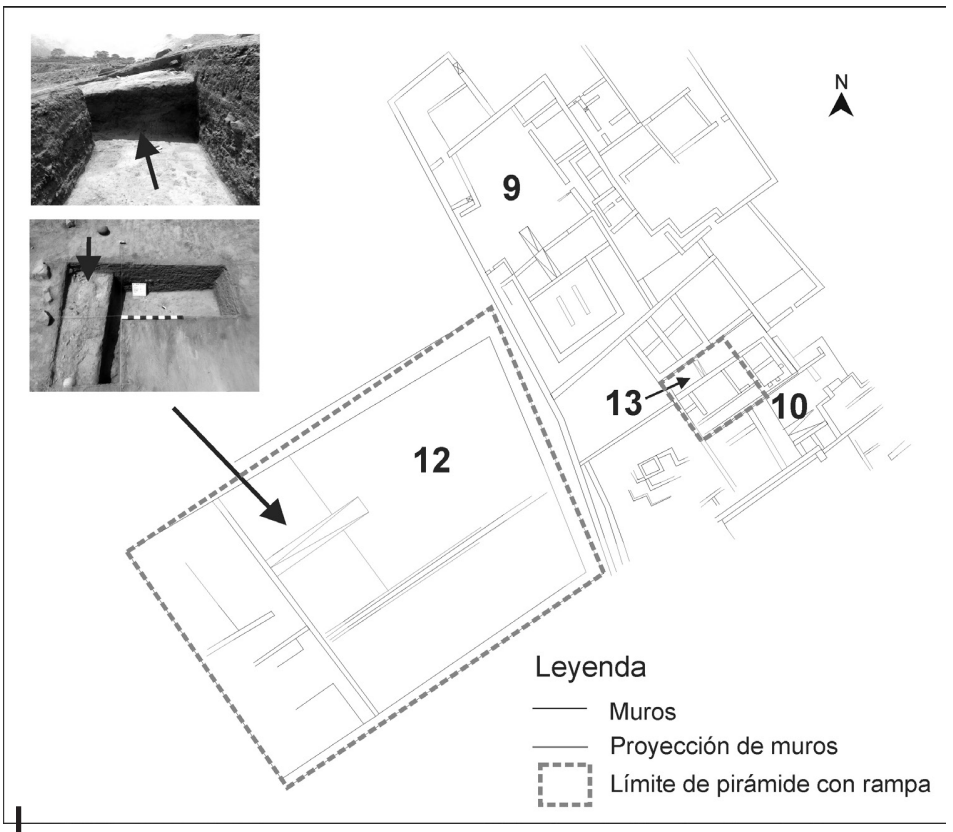

Figura 3 - Pirámides con Rampa 9, 10, 12 y 13 del Sector 1

Plano elaborado por Alexis Solís; fotos: Proyecto Qhapaq Ñan 
de este edificio se debe en parte a que fue casi íntegramente construido en adobe, a diferencia del resto de edificios cuyas estructuras son principalmente hechas con muros de piedra y barro. Así mismo, entre la PCR 9 y la PCR 10 fue posible identificar los restos parciales de otro de estos edificios, que tampoco había sido identificado previamente (PCR 13) (fig. 3).

Con respecto a la técnica constructiva, como ya mencionamos, se estableció que estos edificios fueron hechos utilizando dos técnicas: muros de piedras canteadas unidas con barro y grandes adobes paralelepípedos hechos en gaveras, también unidos con barro. Se observó también que varias de las PCR han sido edificadas superponiéndose a pirámides más antiguas, lo que sugeriría, tal como propone Eeckhout (2003b), que estos edificios habrían sido construidos y utilizados en diferentes momentos.

En cuanto a la distribución espacial de los edificios, la dinámica de circulación en Pampa de Flores se reguló a través de corredores que conectaron los diferentes conjuntos arquitectónicos del asentamiento de modo longitudinal y transversal, como se observa claramente en el Sector 1. Durante los trabajos de levantamiento planimétrico pudimos observar evidencias en superficie que sugieren que la trocha por la cual se ingresa actualmente a este sector sigue el eje longitudinal principal del asentamiento, que fue conformado, entre otros, por los muros perimetrales de las PCR 6, 8, 9 y 12 . Hacia el final de su recorrido se cruza con un eje transversal conformado por los muros perimetrales de las PCR 14, 1, 2, 3 y 6 y por los muros de los conjuntos habitacionales 18 y 19 (fig. 2).

Las edificaciones ubicadas al extremo sur del Sector 1 fueron construidas respetando los ejes antes mencionados, pero además están alineadas formando un gran conjunto que incluye las PCR 1, 2, 3 y 14, además de los conjuntos habitacionales 18 y 19 (fig. 4). Sus muros perimetrales configuran pasillos de 1,50 metros de ancho en promedio y articulan cada uno de los edificios a modo de pasajes longitudinales y transversales. Se observa también que hacia el suroeste continúan las construcciones en este mismo eje aunque se encuentran muy afectadas en la actualidad, sobre todo por remociones modernas en el terreno.

La disposición de estas estructuras y de la adecuada articulación por pasillos regulares sugiere que todos estos conjuntos fueron construidos de modo planificado y organizado, tratándose probablemente de las primeras construcciones monumentales en el Sector 1. La evidencia arquitectónica en superficie indica que los edificios más antiguos serían las PCR 1 y 2 y que las PCR 3 y 14 se habrían construido posteriormente, superponiéndose a las primeras, pero siguiendo la misma orientación (fig. 3)3. El resto de PCR y conjuntos habitacionales del Sector 1 , si bien siguen la orientación de los ejes principales, ya no se articulan mediante corredores, ni se alinean con el conjunto antes mencionado. Esto indicaría un

3 De acuerdo a nuestra numeración, la PCR 14 formaría parte de lo que Eeckhout considera una de las fases constructivas de la PCR 1 (2003a). Nuestra clasificación se basa en la consideración de una PCR de acuerdo a los componentes antes mencionados (plaza, plataformas, rampa), tomando en cuenta que la superposición de estas edificaciones se da en todo el asentamiento y no necesariamente como una fase en su construcción. 


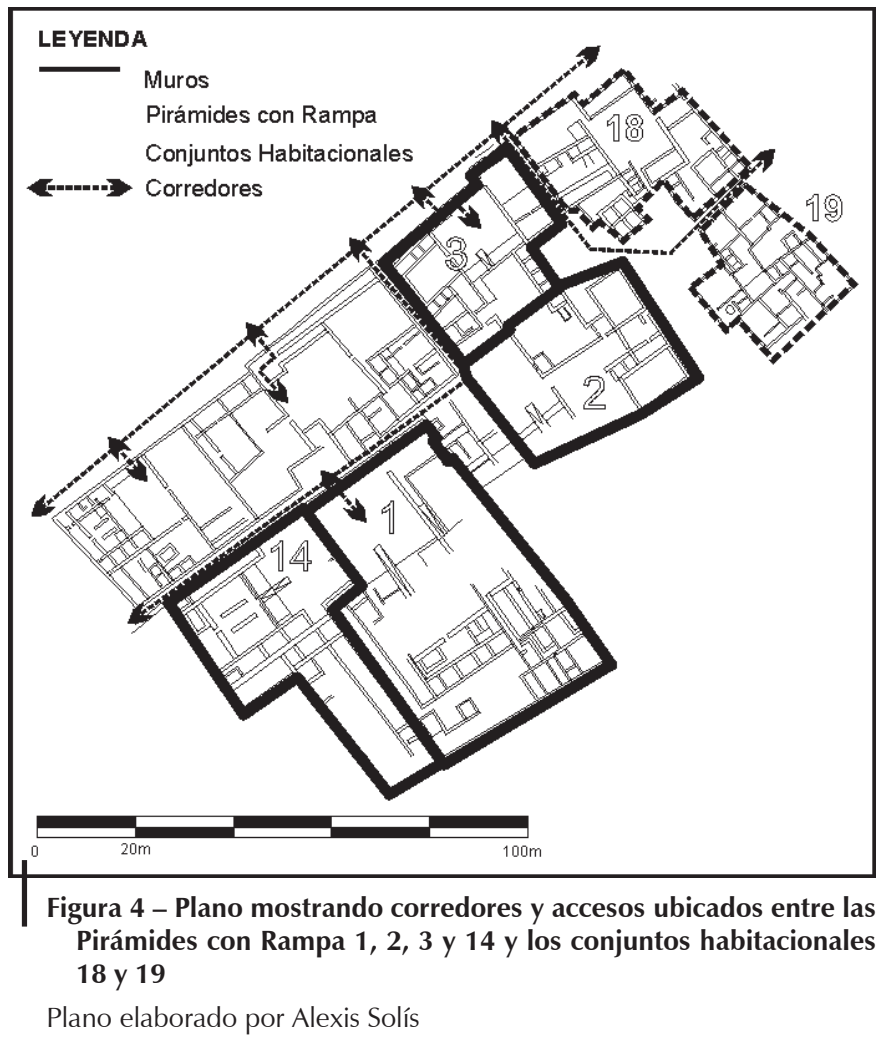

crecimiento progresivo del sitio durante el cual el resto de edificios se habría construido de manera paulatina e independiente. Esta idea se ve reforzada por la información recuperada durante las diferentes excavaciones que han sido realizadas en el sitio y con los resultados del análisis de la cerámica hallada durante nuestras excavaciones, en asociación con los niveles de ocupación y los rellenos constructivos.

De acuerdo a lo reportado por Eeckhout, por ejemplo, la PCR 3 habría sido construida hacia finales del Intermedio Tardío. El investigador realizó excavaciones en la plaza, la rampa, la plataforma superior y uno de los recintos anexos. Con base en los resultados obtenidos pudo establecer que la pirámide fue construida sobre una ocupación doméstica previa, durante el Intermedio Tardío y posteriormente remodelada durante el Horizonte Tardío (Eeckhout, 1998: 85).

Con respecto a la PCR 4, Dulanto excavó sobre la plataforma superior, la plataforma intermedia y los recintos anexos de la estructura. Sin embargo solo profundizó la excavación, por debajo de la última fase ocupacional, en la unidad de la plataforma intermedia y en dos de los recintos anexos, hallando un total de tres niveles de ocupación. En asociación con un segundo piso hallado en la plataforma intermedia, el autor encontró «una olla Ychsma de asas laterales horizontales y con diseños 
serpentiformes» (Dulanto, 2002: 9) que, de acuerdo a sus características pertenecería a la fase Ychsma Tardío B del Horizonte Tardío (Feltham \& Eeckhout, 2004: 670; Vallejo, 2004: 630). Adicionalmente, este segundo piso también es hallado en los dos recintos anexos, aunque se extiende por debajo de sus muros indicando que se trataría de una fase constructiva anterior. Finalmente encontró un tercer piso que correspondería a la primera fase constructiva. En resumen, el autor muestra la evolución del edificio en, al menos, tres fases, con la edificación inicial de un núcleo piramidal (segundo y tercer piso) y la posterior construcción de recintos y otras estructuras anexas (primer piso) (Dulanto, 2002: 9 y 10). Si bien Dulanto no establece el momento inicial de construcción del edificio, podemos inferir que, por lo menos desde su fase intermedia, estaría asociado al Horizonte Tardío.

En nuestras excavaciones, en la PCR 8 se pudo identificar al menos dos fases constructivas: una primera que pertenece a una edificación anterior al volumen piramidal y una segunda en la que estas estructuras fueron cubiertas por la construcción del piso de la plaza de la PCR. Asociado a los rellenos constructivos de ambas fases, fue posible identificar cerámica del estilo Ychsma Tardío B (fragmentos de ollas con círculos estampados, fragmentos de cántaros cara-gollete, etc.). Se halló también un fragmento de plato de estilo inca sobre el piso de la plaza. En la PCR 12 se excavaron hasta dos fases constructivas, hallando también material cerámico asociado al estilo Ychsma Tardío B en ambos rellenos. Por otra parte, en la PCR 9 no fue posible determinar el momento de construcción, pero el material cerámico asociado a la última fase constructiva estaría claramente vinculado al Horizonte Tardío local (cántaros cara-gollete, vasijas de estilo Chimú-Inca, ollas con serpientes aplicadas en el cuerpo, etc.). En cuanto a las PCR 10 y 11, no se obtuvo mayor información referente a las fases constructivas de los edificios.

En ninguno de los casos, salvo el fragmento de plato mencionado para la PCR 8, el material cerámico aludido proviene de lo que podría ser considerado como una reocupación tardía similar a lo que explica Eeckhout y mencionada líneas arriba. Todos los fragmentos provienen de rellenos constructivos o asociados a pisos o contextos de las primeras fases constructivas de los edificios.

En resumen, al menos una de las PCR excavadas habría sido construida durante el Intermedio Tardío y remodelada durante el Horizonte Tardío, mientras que las demás fueron probablemente construidas y utilizadas en el Horizonte Tardío. La cerámica vinculada a esta última fase pertenece al denominado estilo Ychsma Tardío B (Vallejo, 2004) y se encuentra en asociación con los estilos Inca y Chimú Inca. Adicionalmente, la introducción de adobes paralelepípedos en remodelaciones y nuevas construcciones se encuentra asociada también al Horizonte Tardío, pudiendo relacionarse a la presencia inca en el asentamiento (Díaz, 2004).

Esta información, junto a aquella obtenida mediante el levantamiento planimétrico, nos permite sugerir que el sitio habría crecido drásticamente durante el Horizonte Tardío, con la construcción de nuevas pirámides. Del mismo modo en que se incrementa el número de edificios monumentales, también continúan construyéndose y expandiéndose los conjuntos habitacionales a tal 
punto de llegar a reocupar espacios con presencia de arquitectura monumental, tal y como se observa en el caso de la PCR 5, la cual desaparece parcialmente tras la construcción del Conjunto Habitacional 17 (ver fig. 2). Es probable que al momento del crecimiento del conjunto habitacional, la PCR en mención ya se encontrara abandonada, lo que permitió el desmontaje o destrucción de su patio principal.

La superposición de edificios nos permite inferir, además, que la PCR 3 no sería el único edificio temprano en el sitio. Como hemos mencionado anteriormente, la construcción de las PCR 1 y 2 parecería ser anterior. Es así que podríamos considerar que al menos el núcleo arquitectónico mostrado en la figura 4 correspondería al Intermedio Tardío, mientras que gran parte del resto de pirámides y del asentamiento en general dataría del Horizonte Tardío.

\section{EL ESCENARIO POLÍTICO ANTES Y DESPUÉS DE LOS INCAS}

La propuesta que presentamos para analizar los cambios ocurridos con la llegada de los incas se basa en dos ejes de estudio: un análisis de rango-tamaño de las comunidades de esta determinada región, siguiendo lo establecido en un modelo propuesto por Peterson \& Drennan (2005) y los cambios y continuidades en el uso de edificios público-administrativos en los asentamientos, ocurridos entre el Intermedio Tardío y el Horizonte Tardío, centrándonos en el caso de Pampa de Flores.

Las primeras referencias al Señorío de Ychsma provienen de fuentes etnohistóricas en donde se señala que este grupo habría habitado los valles del Lurín y del Rímac durante el Intermedio Tardío y el Horizonte Tardío (Rostworowski, 1978). Sin embargo, estas fuentes se explayan más sobre las divisiones políticas y territoriales que se habrían implementadas bajo el régimen imperial (Paredes Botoni, 2004). Las propuestas más específicas referentes a una unidad política de poblaciones asentadas en estos valles durante el Intermedio Tardío se basan en la evidencia arqueológica, siendo aún este un tema de debate (Eeckhout, 1999; 2003a; Feltham, 1983; Rostworowski, 1972). Han sido muchas las investigaciones que han dado cuenta en los últimos años de una serie de características culturales compartidas en esta región, especialmente aquellas vinculadas al material cerámico. Estudios como los realizados por Jane Feltham \& Peter Eeckhout (2004) y por Francisco Vallejo $(1998 ; 2004)$ confirman la recurrencia de ciertas características tales como la presencia de cántaros cara-gollete (fig. 5), ollas con serpientes aplicadas y figurinas hechas con moldes, entre otras. Los rasgos culturales tales como la forma y decoración de vasijas de cerámica, la repetición de diseños iconográficos sobre una variedad de soportes y las características arquitectónicas ampliamente descritas líneas arriba, habrían variado de acuerdo a la ubicación de los asentamientos.

Una primera aproximación para entender la organización política del valle bajo de Lurín durante estos periodos puede verse mediante lo que Peterson \& Drennan (2005) describen como un análisis de rango-tamaño, a través del cual se analiza la relación entre el tamaño de los asentamientos, como punto 


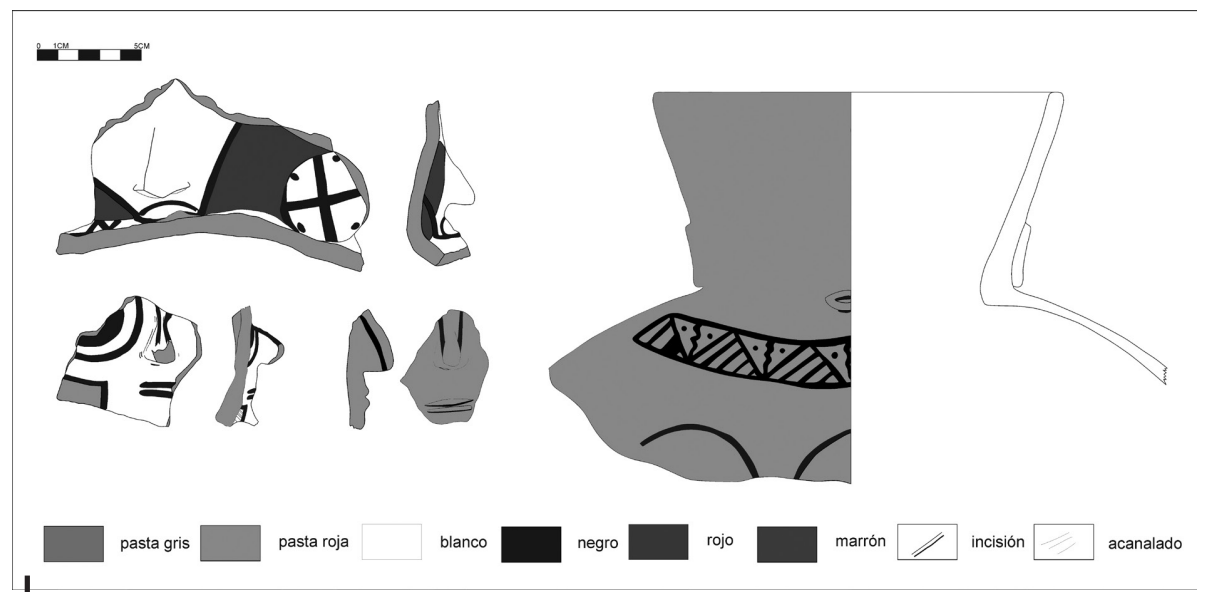

Figura 5 - Fragmentos de cántaros cara-gollete del estilo Ychsma Tardío B hallados en Pampa de Flores

Dibujos elaborados por Martha Guzmán

de partida, para ver de qué forma estos se interrelacionan. Si bien la propuesta original se basa en un estimado poblacional de las comunidades, en este caso, dada la buena preservación de los sitios, se tomó como referencia el total del área construida que se preserva en superficie en cada asentamiento. Los resultados expuestos se basan en la arquitectura visible hoy en día; por ello, estaríamos hablando de la extensión de los asentamientos previo a su abandono. Como ya lo hemos mencionado, la mayor parte de estos sitios fueron ocupados hasta el Horizonte Tardío, y salvo en Pachacamac, no existe mayor evidencia que sugiera una continuidad de uso durante la Colonia. Por otro lado, la presencia de conjuntos habitacionales en casi todos estos lugares, a excepción de Pachacamac, estaría indicando que se trata de sitios con población permanente, por ende comunidades, entendidas como unidades de interacción entre estructuras domésticas (Peterson \& Drennan, 2005: 6).

Eeckhout realizó un análisis similar con el objetivo de establecer una comparación entre la estructura organizacional del valle durante la Colonia temprana, basándose principalmente en la visita de Andrade de 1573, y aquella que habría funcionado en la época prehispánica (Eeckhout, 2008). Su análisis fue hecho con base en más de 50 sitios arqueológicos tardíos del valle, muchos de ellos registrados en la década de los años 1960 por Patterson y su equipo. Lamentablemente, como también lo expresa el autor, muchos de estos asentamientos no se han mantenido hasta la actualidad y, en consecuencia, resulta difícil tener un verdadero panorama de lo que fue el valle de Lurín en la época prehispánica.

En cuanto a nuestro análisis, entre los criterios que utilizamos para definir nuestra muestra están: el tamaño, el estado de conservación y la presencia de componentes múltiples en los asentamientos (áreas residenciales, áreas públicas, arquitectura monumental, cementerios, etc.). Por ello, se trataría de aquellas comunidades de 
mayor tamaño y con una organización hasta cierto punto independiente. Nuestra muestra comprendió los sitios de Pachacamac, Pampa de Flores, Quebrada Golondrina, Tijerales, Panquilma, Villa Toledo, Huaycán de Cieneguilla, Molle, Río Seco y Chontay. Todos ellos habrían sido ocupados durante el Intermedio Tardío, y en principio también durante la época Inca (fig. 6). La muestra no incluyó otros asentamientos contemporáneos de menor tamaño en el valle como Pacae Redondo o Tambo Inga pues estos no parecen ser multicomponentes.

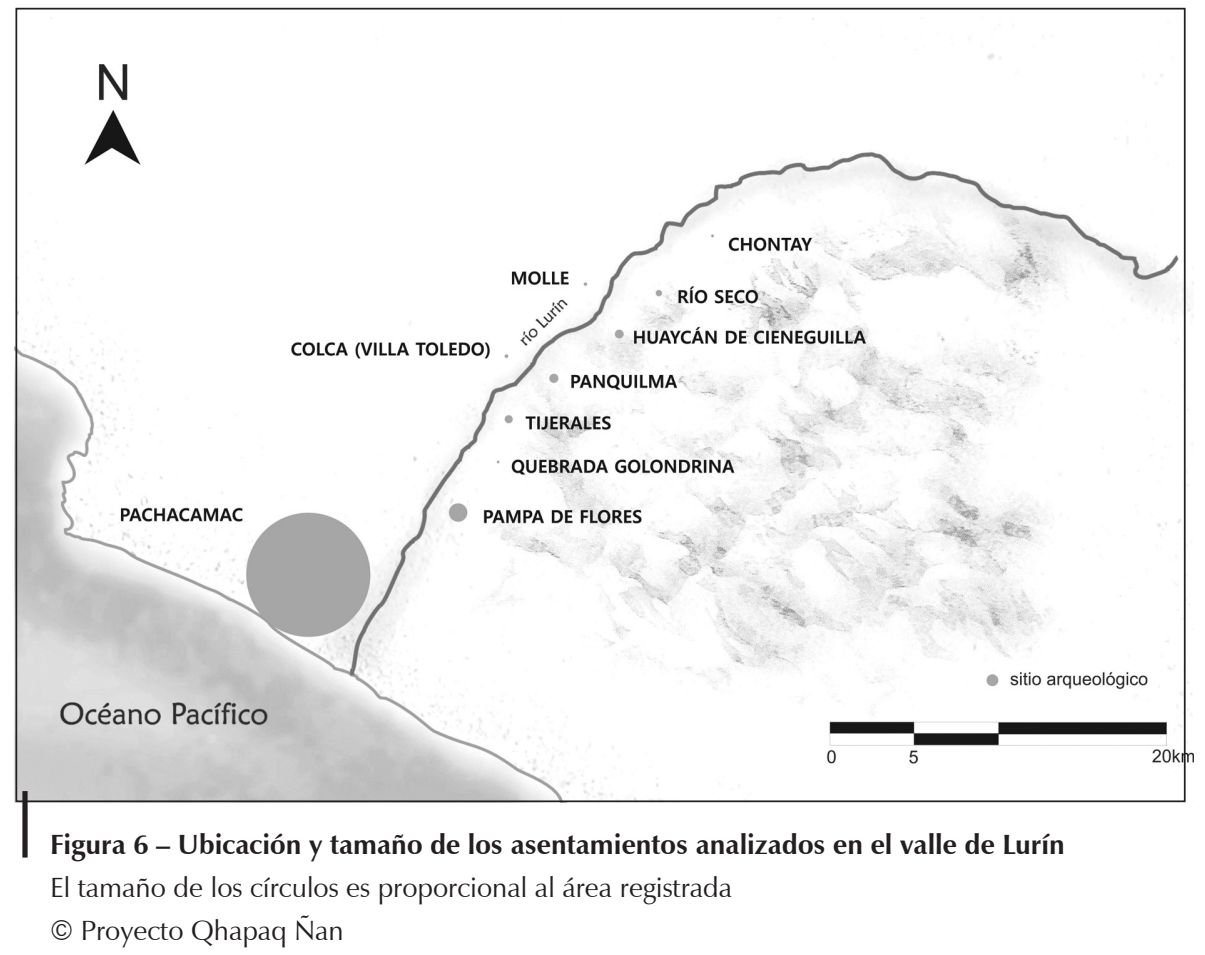

Un primer gráfico elaborado con base en toda la muestra arrojó como resultado una curva muy cóncava en relación con la línea de proporción normal. Esta indicaría, de acuerdo a lo establecido para el análisis de rango-tamaño, el patrón esperado para un sistema organizacional bien integrado y centralizado, en donde existe un claro orden jerárquico con asentamientos que disminuyen en tamaño de forma proporcional. Este resultado no es sorprendente, dado que Pachacamac supera ampliamente en tamaño al segundo mayor asentamiento de esta región que sería Pampa de Flores. Los demás asentamientos del valle estarían muy por debajo del tamaño de los dos primeros (fig. 7a).

Sin embargo, aunque Pachacamac tuvo una clara importancia dentro del sistema del valle, es el único sitio que no cuenta, al menos de modo visible hoy, con áreas residenciales. En un segundo análisis que solo contemplaría los sitios con conjuntos habitacionales, Pampa de Flores aparece como el asentamiento de mayor tamaño. 
Pampa de Flores: cambios y continuidades a la llegada de los incas en el valle de Lurín
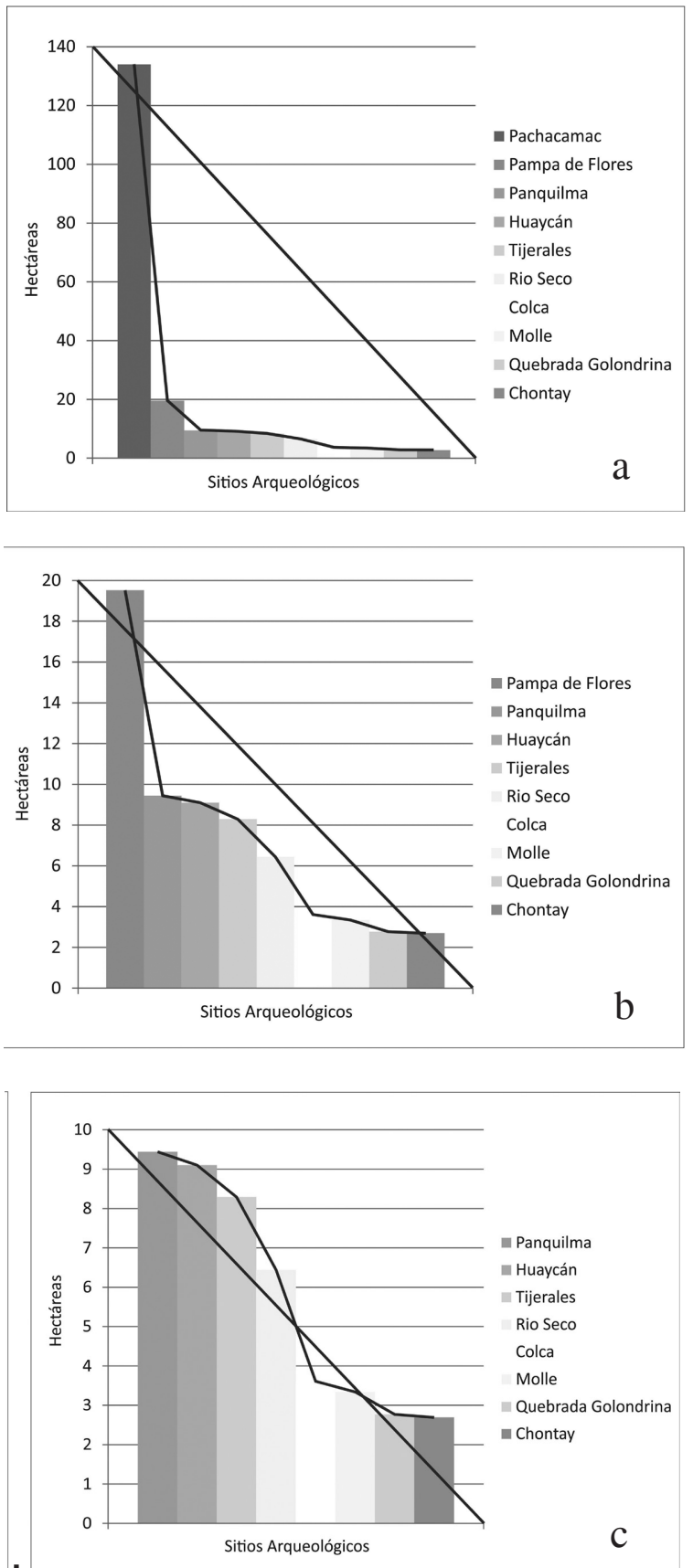

Figuras 7a, b y c - Resultados del análisis rango-tamaño en los asentamientos del valle de Lurín

Elaboración: Camila Capriata Estrada 
Pudimos observar que la línea se mantenía cóncava, aunque no tan marcadamente como en el primer gráfico. Esto estaría indicando que Pampa de Flores, al nivel de las comunidades, mantuvo un alto estatus dentro del valle (fig. $7 \mathrm{~b}$ ).

Finalmente, con el objetivo de establecer las relaciones internas entre las comunidades jerárquicamente por debajo de Pampa de Flores, se repitió el análisis observándose esta vez como resultado una curva convexa, lo cual indicaría que se trataría de un sistema no integrado ni centralizado. Este resultado nos permitió establecer, aunque sea de forma preliminar, que entre el resto de asentamientos no habría existido una relación jerárquica tan marcada, es decir que se trató de una serie de sitios relativamente similares, por lo menos en cuanto a su tamaño (fig. 7c).

Posteriormente, utilizamos la presencia de arquitectura monumental y el tamaño de los espacios de uso público como variables añadidas a nuestro análisis. En el caso de Pachacamac y Pampa de Flores, por ejemplo, ambas variables se correlacionaban directamente al tamaño de los asentamientos. Es decir, los de mayor tamaño son los que cuentan con más arquitectura monumental y espacios de uso público. En el caso del resto de comunidades del valle, esta relación no parece haber existido, es decir que no necesariamente hubo más edificios monumentales en los sitios de mayor extensión.

En este escenario, Pampa de Flores destaca sobre los demás asentamientos del valle no solo por su tamaño, sino por la presencia de al menos catorce edificios monumentales denominados Pirámides con Rampa. Luego de Pachacamac, no existe ningún otro sitio en la zona que presente tantas edificaciones de este tipo. El hecho de tener un asentamiento con estas características tan cerca de Pachacamac y que no ocurra en otros poblados del valle, ha llevado Peter Eeckhout a proponer no solo que debió existir una relación estrecha entre ambos, sino que esta posiblemente se basó en los principios de dualidad existentes en los Andes prehispánicos (Eeckhout, 2008). A partir de esto, el autor sugiere que Pachacamac habría pertenecido a la mitad baja o hurin, mientras que Pampa de Flores habría representado la mitad alta o hanan (Eeckhout, 2003a). Más allá del tipo de relación entre ambos asentamientos, es claro que Pampa de Flores cumplió un rol importante en el desarrollo político del valle.

Si bien es cierto que se observa esta dualidad entre estos dos asentamientos, esto no parece repetirse tan claramente en el resto del valle. Nuestro análisis, como lo mencionamos anteriormente, tomó en cuenta además del tamaño, la ubicación y las características arquitectónicas en estos asentamientos. En un análisis a ser publicado, Zambrano (2016) propone que hacia finales del Intermedio Tardío y durante el Horizonte Tardío la población local del valle bajo de Lurín estuvo organizada en dos grupos sociales, basándose en ciertas características como la presencia de edificios monumentales y públicos como las Pirámides con Rampa y las audiencias, el patrón funerario y la presencia de frisos, entre otros. Uno de los grupos habría estado conformado por los asentamientos ubicados entre los sitios de Pachacamac y Panquilma y otro por los sitios entre Huaycán de Cieneguilla y Chontay. Esta nueva propuesta, a grandes rasgos es similar a la que presenta Eeckhout (2008) con la diferencia de que Zambrano propone una distribución de 
áreas y asentamientos diferente. Además, resalta, entre otras cosas, la presencia de un edificio «tipo» (PCR y Audiencias) para cada uno de los grupos y señala al Santuario de Pachacamac y a Huaycán de Cieneguilla como los asentamientos líderes. Esto contrasta, además con otros estudios previos: por un lado, los límites entre los dos grupos se definirían con base en las características antes mencionadas y no coincidirían plenamente con aquellos límites geográficos propuestos por Marcone (2004); y por otro lado, la zona de ocupación Yunga se extendería hasta el asentamiento arqueológico de Chontay; desde ahí hacia arriba, la presencia de grupos serranos o yauyos parece ser más notoria.

Los resultados del análisis de rango-tamaño nos llevan a proponer la existencia de un paisaje social y político complejo durante los periodos tardíos, con una serie de asentamientos similares en tamaño que no muestran jerarquía entre sí, y dos grandes centros a la cabeza: Pachacamac y Pampa de Flores. La ubicación geográfica de estos dos centros resulta determinante para comprender su trascendencia, puesto que ambos están ubicados cerca del cono de deyección del valle, en donde el área cultivable es mayor a la del resto del valle.

\section{CAMBIOS, TRANSFORMACIONES Y CONTINUIDADES A LA LLEGADA DE LOS INCAS}

La llegada de los incas a la costa central trajo cambios políticos al valle. En Pachacamac, como ya lo mencionamos, los incas construyeron una serie de nuevos edificios residenciales, administrativos y ceremoniales bajo sus estándares arquitectónicos (Eeckhout, 2010; López-Hurtado \& Nesbitt, 2010). En el valle, el impacto de la conquista inca parece haber sido menor, ya que no se construyeron grandes palacios ni templos en estos poblados. Sin embargo, sí habría habido cambios a nivel de las organizaciones políticas locales, influenciadas tanto por la presencia imperial, como por el rápido crecimiento de Pachacamac, que empezaba a situarse como uno de los mayores centros religiosos y administrativos del imperio.

Estos cambios se ven reflejados en la arquitectura y en el registro arqueológico de los diferentes asentamientos; parecen variar en complejidad dependiendo de la función e importancia que habrían tenido estos durante el Horizonte Tardío. Por ejemplo, recientes estudios en Panquilma, un asentamiento ubicado a veintidós kilómetros al noreste de Pachacamac, sugieren que las PCR presentes en el sitio, construidas durante el Intermedio Tardío, habrían sido no solo abandonadas sino también quemadas y cerradas ritualmente durante el Horizonte Tardío. Adicionalmente, si bien la ocupación en Panquilma continúa durante este periodo, no se ha registrado la construcción de nuevos edificios monumentales. Esto podría sugerir un colapso a nivel político en el asentamiento, probablemente vinculado a la llegada de los incas (Capriata \& López-Hurtado, 2017).

En Huaycán de Cieneguilla, ubicado a dos kilómetros al noreste de Panquilma, se construyeron nuevos edificios con clara influencia inca durante el Horizonte 
Tardío (López-Hurtado \& Nesbitt, 2010), además de realizarse una serie de modificaciones arquitectónicas en otros espacios. Según Marcone, se trata del único asentamiento del valle de Lurín que presenta arquitectura con rasgos incaicos, sugiriendo que esta evidencia reflejaría un manejo indirecto por parte de los incas, quienes habrían adquirido control de este asentamiento a través de su influencia sobre los gobernantes locales. En el caso de Huaycán, esta situación habría generado un incremento de poder en las elites locales que como consecuencia situó al asentamiento en una mejor posición jerárquica con respecto a otros asentamientos como Panquilma (Marcone 2004).

En el caso de Pampa de Flores, ubicado a mitad de camino entre Huaycán y Pachacamac, el asentamiento continuó expandiéndose durante el Horizonte Tardío con la construcción de nuevas PCR y de conjuntos habitacionales. Como se mencionó previamente, el sitio habría ido creciendo a partir de la organización en dos ejes centrales. En algunas ocasiones las nuevas construcciones se superpusieron a las antiguas, probablemente luego de su abandono. Los nuevos edificios mantuvieron los patrones arquitectónicos originales, pero introdujeron grandes adobes en su construcción. Este nuevo elemento arquitectónico también aparece asociado a reparaciones, remodelaciones y ampliaciones de estos edificios. Este cambio se da en las últimas fases constructivas y estaría asociado con la presencia de cerámica de los estilos Ychsma Tardío B, Chimú Inca e Inca (figs. 5, 8), indicando una continuidad en el uso de estos edificios. Un caso similar ha sido reportado por Luisa Díaz (2004) para el sitio arqueológico de Armatambo, en el que registra una superposición de técnicas arquitectónicas similar.

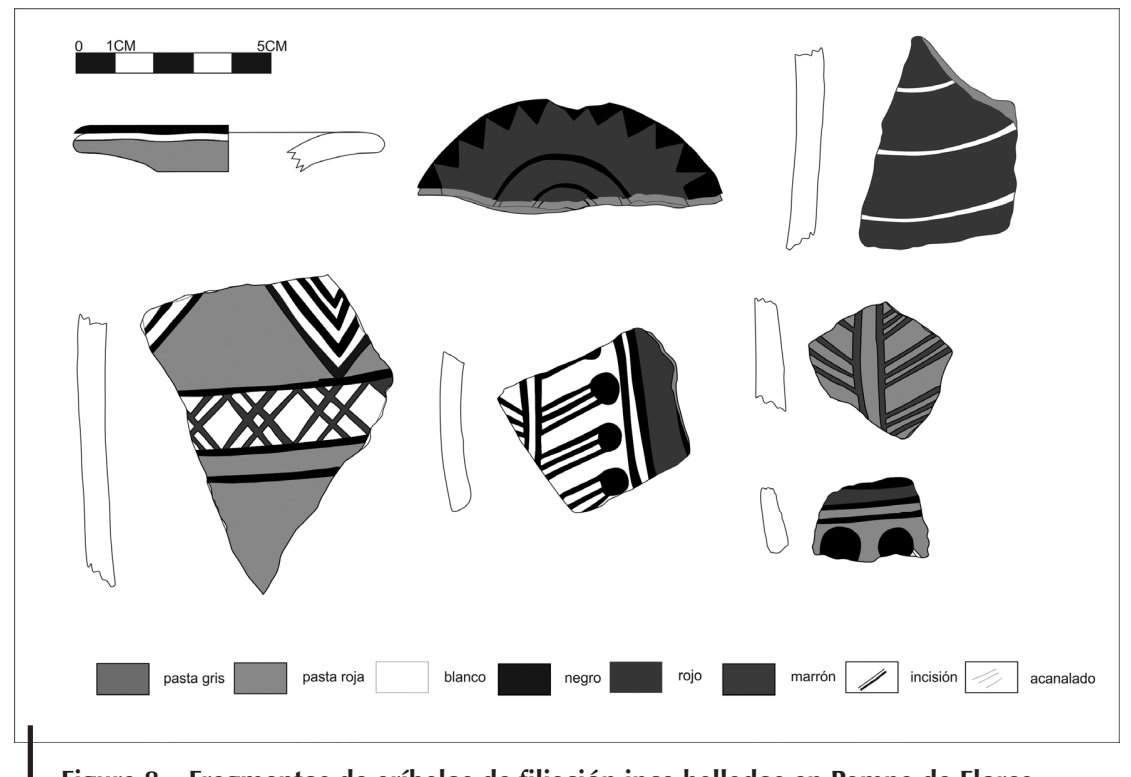

Figura 8 - Fragmentos de aríbalos de filiación inca hallados en Pampa de Flores

Dibujos elaborados por Martha Guzmán 
Parte de los cambios durante el Horizonte Tardío están relacionados con la aparición de asentamientos conformados por grupos yauyos o de origen serrano en la parte baja del valle de Lurín, las cuales ocuparon la zona de lomas en el extremo sur del valle y de modo transversal desde la quebrada El Manzano hasta las proximidades del valle de Chilca. Un claro ejemplo es el sitio arqueológico Pueblo Viejo-Pucará. Investigaciones en el sitio han determinado que este asentamiento fue construido a partir del Horizonte Tardío y su población habría estado conformada por mitimaes procedentes de la parte alta del valle de Lurín (Makowski et al., 2005).

En este contexto, la evidencia sugiere que Panquilma continuó siendo ocupado durante el Horizonte Tardío, pero sus principales edificios ceremonialesadministrativos habrían sido abandonados. En este sentido, las elites de Panquilma se habrían visto afectadas por la conquista inca, produciéndose así cambios en la función de este asentamiento y en su jerarquía dentro del valle, ambos hechos reflejados en el abandono de estos edificios (Capriata \& López Hurtado, 2017). Huaycán, por otro lado, parece haber resurgido, cobrando mayor importancia durante la época inca. Las nuevas construcciones, al igual que en Pachacamac, no solo reflejarían una continuidad en el uso del asentamiento, sino también una transformación tanto a nivel físico como político.

En Pampa de Flores, el escenario parece ser distinto. La continuidad en el uso de PCR sugiere que la organización social y política continuó a cargo de las elites locales, las cuales se habrían visto beneficiadas con la llegada de los incas. Por ello, el asentamiento creció con la construcción de nuevas pirámides y conjuntos habitacionales. A diferencia de Pachacamac, Pampa de Flores no sufrió grandes transformaciones, sino más bien existió una continuidad con un crecimiento progresivo del asentamiento hasta su abandono.

\section{CONCLUSIONES}

Los resultados de un análisis con base en el rango-tamaño de los asentamientos del valle de Lurín en los periodos tardíos, sugiere la existencia de una compleja red de asentamientos, en donde Pachacamac y Pampa de Flores se ubican jerárquicamente por encima del resto de poblados. Al mismo tiempo, este análisis indica que en el resto del valle los asentamientos fueron similares en tamaño y quizá también en jerarquía. En estos lugares las elites locales habrían tenido el control político y económico de cada sitio y probablemente habrían competido entre sí por adquirir un mayor estatus. Este escenario concuerda con la evidencia arqueológica, especialmente aquella vinculada a la arquitectura monumental.

A diferencia de las evidencias halladas en Pachacamac y Huaycán de Cieneguilla, que sugieren una transformación en la arquitectura pública durante la época inca, o la evidencia proveniente de Panquilma que sugiere más bien el abandono de su arquitectura pública durante este periodo, en el caso de Pampa de Flores, 
toda la evidencia apunta a una continuidad en el uso de sus PCR. En términos arquitectónicos la introducción del uso de adobes es lo único que sugiere la presencia inca en el sitio. En general, el uso de elementos incas como los accesos trapezoidales, no solía ser común en asentamientos provinciales; en el caso de haber sido usados, estos aparecían de forma restringida en edificios de particular importancia (Malpass, 1993). Como ya se mencionó, hasta el momento estos elementos solo han sido registrados en Huaycán de Cieneguilla, aunque cabe resaltar que son muy escasos. En el resto del valle, la presencia imperial se manifiesta a través de la cerámica (fig. 8) y otros objetos muebles de estilo inca, así como en la infraestructura vial asociada.

Así mismo, los datos estarían reflejando un cambio en la organización política del valle en donde ciertos asentamientos habrían adquirido mayor importancia, mientras que otros habrían pasado a cumplir roles secundarios o habrían sido parcialmente abandonados. Para el caso de Pampa de Flores, la continuidad en el uso de las pirámides indicaría que el sitio no sufrió grandes cambios a nivel social y político. Esta continuidad en el diseño arquitectónico sería un reflejo de la estrategia política inca, en donde en palabras de Villacorta, «los incas respetaron el sistema previo, en virtud de su eficiencia económica»; los cambios se habrían limitado a «elevar la productividad mostrada, pero sobre la base del mismo sistema de organización» (Villacorta, 2004: 566).

La evidencia recuperada parece concordar con el modelo planteado por Eeckhout (2003a; 2003b) que sugiere que estos edificios habrían funcionado como palacios o residencias de elite. El autor sugiere además que no todos los señores habrían gobernado simultáneamente. Los datos provenientes de Pampa de Flores apoyan esta hipótesis y permiten añadir que más de una pirámide funcionó de forma simultánea. En consecuencia, dos o más señores habrían coexistido a manera de facciones, quizá competiendo por el prestigio y el acceso a recursos dentro del asentamiento (Brumfiel \& Fox, 1994).

La evidencia parece indicar que el rol cumplido por Pachacamac y Pampa de Flores como los mayores centros en el valle de Lurín, no varió durante el Horizonte Tardío. Los cambios y continuidades en estos dos lugares fueron positivos, manteniendo o incrementando su poder a través de su crecimiento espacial. Un aspecto que sí varió fue probablemente la relación que tuvieron estos centros con los asentamientos de menor tamaño en el valle, ya que en algunos casos sus elites se vieron afectadas de forma negativa con la conquista inca, perdiendo estatus sobre el resto de asentamientos.

\section{Agradecimientos}

El trabajo presentado analiza los resultados obtenidos en el «Proyecto de Investigación Arqueológica Pampa de Flores con Fines de Diagnóstico para su Puesta en Valor» que fue realizado entre los años 2013 y 2014 como parte de los trabajos que viene realizando el Qhapaq Ñan-Sede Nacional del Ministerio de Cultura del Perú en el tramo de camino Xauxa-Pachacamac. Un especial agradecimiento a todo el equipo que trabajó en este proyecto: Edines Pebe, Alexis Solís, Marcela Najarro, Martha Guzmán, Lucía Rengifo, Alex Ramos y Waldir Nieto. 
Pampa de Flores: cambios y continuidades a la llegada de los incas en el valle de Lurín

\section{Referencias citadas}

BAZÁN, F., 1990 - Arqueología y Etnohistoria de los Períodos Pre Hispánicos Tardíos de la Costa Central de Perú; Lima: Universidad Nacional Mayor de San Marcos, Escuela Academico Profesional de Arqueología. Tesis de licenciatura.

BRUMFIEL, E. M. \& FOX, J. W. (eds.), 1994 - Factional competition and political development in the New World, 234 pp.; Cambridge [England], Nueva York: Cambridge University Press. New directions in archaeology.

BUENO, A., 1983 - El antiguo valle de Pachacamac: espacio, tiempo y cultura (segunda parte). Boletín de Lima, 25 (5): 5-26.

CAPRIATA, C., 2014 - Informe Final del Proyecto de Investigación Arqueológica Pampa de Flores con Fines de Diagnóstico para su puesta en Valor; Lima: Proyecto Qhapaq Ñan, Ministerio de Cultura del Perú.

CAPRIATA, C. \& LÓPEZ-HURTADO, E., 2017 - The demise of the ruling elites: termination rituals in the pyramid complexes of Panquilma, Peruvian Central Coast. In: Rituals of the past. Prehispanic and colonial case studies in Andean Archaeology (S. Rosenfeld \& S. Bautista, eds.): 193-215; Boulder: University of Colorado Press.

CAPRIATA, C., ZAMBRANO, R. \& SOLÍS, A., 2014 - La Ocupación Inca en Pampa de las Flores: Continuidad, transformación y abandono de arquitectura pública en el valle de Lurín durante el Horizonte Tardío. In: Actas del primer Congreso Nacional de Arqueología I: 197-207; Lima: Ministerio de Cultura del Perú.

DÍAZ, L., 2004 - Armatambo y la sociedad Ychsma. Bulletin de I'Institut Français d'Études Andines, 33 (3): 571-594; Número temático «Arqueología de la Costa Central del Perú en los periodos Tardíos», editado por P. Eeckhout.

DULANTO, J., 2002 - Informe de la Primera temporada del Proyecto de Investigaciones Arqueológicas en Pampa de las Flores. Presentado al Instituto Nacional de Cultura (INC).

EARLE, T. K., 1972 - Lurín valley, Peru: Early Intermediate period settlement development. American Antiquity, 37 (4): 467-477; Washington D.C.

EECKHOUT, P., 1995 - Pirámide con rampa n. ${ }^{3}$ 3, Pachacamac. Resultados preliminares de la primera temporada de excavaciones (zonas 1 y 2). Bulletin de I'Institut Français d'Études Andines, 24 (1): 65-106.

EECKHOUT, P., 1998 - Sondeos arqueológicos en el valle bajo y medio del río Lurín. Informe final. Presentado al Instituto Nacional de Cultura (INC).

EECKHOUT, P., 1999 - Pachacamac durant I'Intermédiaire récent. Étude d'un site monumental préhispanique de la Côte centrale du Pérou, 504 pp.; Oxford: British Archaeological Reports International Series 747.

EECKHOUT, P., 2000 - Los antecedentes formales y funcionales de las pirámides con rampa' de la Costa Central del Perú en los tiempos prehispánicos. Boletín Americanista, 50: 39-60.

EECKHOUT, P., 2003a - Ancient Monuments and Patterns of Power at Pachacamac, Central Coast of Perú. Beitrage zur Allgemeine und Vergleichenden Archaologie, 23: 139-182.

EECKHOUT, P., 2003b - Diseño arquitectonico, patrones de ocupación y formas de poder en Pachacamac, Costa central del Perú. Revista Española de Antropologia Americana, 33: 17-37.

EECKHOUT, P., 2004 - La Sombra de Ychsma. Ensayo introductorio sobre la arqueología de la Costa Central del Perú en los periodos tardíos. Bulletin de l'Institut Français 
d'Études Andines, 33 (3): 403-423; Número temático «Arqueología de la Costa Central del Perú en los Periodos Tardíos», editado por P. Eeckhout.

EECKHOUT, P., 2008 - Poder y Jerarquías Ychsmas en el valle de Lurín. Arqueología y Sociedad, 19: 223-240.

EECKHOUT, P., 2010 - Las Pirámides con Rampa de Pachacamac durante el Horizonte Tardío. In: Arqueología en el Perú: nuevos aportes para el estudio de las sociedades andinas prehispánicas (R. Romero Velarde \& T. Pavel Svendsen, eds.): 415-434; Lima: Universidad Nacional Federico Villarreal.

FARFÁN, C., 2004 - Aspectos simbólicos de las pirámides con rampa. Ensayo interpretativo. Bulletin de I'Institut Francais d'Études Andines, 33 (3): 449-464; Número temático «Arqueología de la Costa Central del Perú en los Periodos Tardíos», editado por P. Eeckhout.

FELTHAM, J., 1983 - The Lurin Valley, Peru: AD 1000-1532; Londres: Institute of Archaeology, University of London. Ph. D. Diss.

FELTHAM, J. \& EECKHOUT, P., 2004 - Hacia una definición del estilo Ychsma: aportes preliminares sobre la cerámica Ychsma tardía de la pirámide III de Pachacamac. Bulletin de I'Institut Francais d'Études Andines, 33 (3): 643-679; Número temático «Arqueología de la Costa Central del Perú en los Periodos Tardíos», editado por P. Eeckhout.

FRANCO, R., 1993 - Excavaciones en la Pirámide con rampa n. 2, Pachacamac; Lima: Universidad Nacional Mayor de San Marcos. Tesis de licenciatura.

JIMÉNEZ BORJA, A., 1992 - Las Huacas. Pachacamac. Revista del Museo de la Nación, 1: 125-131.

JIMÉNEZ BORJA, A. \& BUENO, A., 1970 - Breves notas acerca de Pachacamac. Arqueología y Sociedad, 4: 13-25.

LÓPEZ-HURTADO, E., 2010 - Pachacamac y Panquilma: Relaciones de Poder Durante el Periodo Intermedio Tardío. In: Arqueología en el Perú. Nuevos aportes para el estudio de las sociedades andinas prehispáncas (R. Romero \& T. Svedsen, eds): 78104; Lima: Universidad Nacional Federico Villareal.

LÓPEZ-HURTADO, E., 2011 - Ideology and the development of social hierarchy at the site of Panquilma, Peruvian central coast; Pittsburgh: University of Pittsburgh, Department of Anthropology. Tesis de doctorado.

LÓPEZ-HURTADO, E. \& NESBITT, J., 2010 - Provincial Religious Centers in the Inka empire: Propagators of Offical Ideology or Spaces for Local Resistance? In: Comparative Perspectives on the Archaeology of Coastal South America (R. Cutright, E. LópezHurtado \& Alexander Martin, eds.): 213-229; Pittsburgh, Lima, Quito: Center for Comparative Archaeology Department of Anthropology University of Pittsburgh, Fondo Editorial de la Pontificia Universidad Católica del Perú, Ministerio de Cultura del Ecuador.

LÓPEZ-HURTADO, E., CAPRIATA ESTRADA, C., VÁSQUEZ MARTÍNEZ, A. \& GONZÁLES LOMBARDI, A., 2014 - Proyecto de Investigación Arqueológica Panquilma. Informe final temporada 2012, 66 pp.; Lima: Instituto de Estudios Peruanos.

MAKOWSKI, K., CORDOVA, M. F., HABETLER, P. \& LIZÁRRAGA, M., 2005 - La plaza y la fiesta: reflexiones acerca de la funcion de los patios en la arquitectura pública prehispánica de los periodos tardíos. Boletin de Arqueologia PUCP, 9: 297-333.

MALPASS, M. A., 1993 - Provincial Inca Archaeology and Etnohistory: An Introduction. In: Provincial Inca. Archaeological and Ethnohistorical Assessment of the Impact of the Inca State (M. A. Malpass, ed.): 1-16; lowa City: University of lowa press. 
Pampa de Flores: cambios y continuidades a la llegada de los incas en el valle de Lurín

MARCONE FLORES, G., 2004 - Cieneguilla a la llegada de los incas. Aproximaciones desde la historia ecológica y la arqueología. Bulletin de l'Institut Français d'Études Andines, 33 (3): 715-734; Número temático «Arqueología de la Costa Central del Perú en los Periodos Tardíos», editado por P. Eeckhout.

MARCONE, G. \& LÓPEZ-HURTADO, E., 2002 - Panquilma y Cieneguilla en la discusión arqueológica del Horizonte Tardío de la Costa Central. Boletín de Arqueología PUCP, 6: 375-394. «Identidad y transformación en el Tawantinsuyu y en los Andes coloniales. Perspectivas arqueológicas y etnohistóricas», primera parte.

MICHCZYŃSKI, A., EECKHOUT, P. \& PAZDUR, A., 2003 - 14C Absolute Chronology of Pyramid III and the Dynastic Model at Pachacamac, Peru. Radiocarbon, 45 (1): 59-73.

PAREDES BOTONI, P., 1988 - Pachacámac - Pirámide con Rampa n. 2. Boletín de Lima, 55: 41-58.

PAREDES BOTONI, P., 2004 - Notas y comentarios respecto a la continuidad de los Señores naturales del linaje de los Savac (Saba) en los padrones y repartimientos de tierras de 1733 y 1787 en el valle del Lurín. Bulletin de I'Institut Français d'Études Andines, 33 (3): 735-782; Número temático «Arqueología de la Costa Central del Perú en los Periodos Tardíos», editado por P. Eeckhout.

PAREDES BOTONI, P. \& FRANCO, R., 1987 - Pachacámac: Las Pirámides con Rampa. Cronología y Función. Gaceta Arqueológica Andina, 13: 5-7.

PETERSON, C. \& DRENNAN, R. D., 2005 - Communities, Settlements, Sites, and Surveys: Regional-Scale Analysis of Prehistoric Human Interaction. American Antiquity, 70 (1): 5-30.

ROSTWOROWSKI, M., 1972 - Breve ensayo sobre el Señorío de Ychma o Ychima. Boletín del Seminario de Arqueología, Instituto Riva Agüero, 13: 37-51.

ROSTWOROWSKI, M., 1978 - Señoríos indígenas de Lima y Canta, 281 pp.; Lima: Instituto de Estudios Peruanos.

ROSTWOROWSKI, M., 2002 - Pachacamac y el Señor de los Milagros / Señoríos indígenas de Lima y Canta; Lima: Instituto de Estudios Peruanos. Obras Completas II.

ROSTWOROWSKI, M., 2004 - Costa Peruana Prehispánica, 376 pp.; Lima: Instituto de Estudios Peruanos.Obras Completas III.

UHLE, M., 1903 - Pachacamac. Report of the William Pepper M.D, LI. D. Peruvian Expeditions of 1896; Philadelfia: Department of Archaeology, University of Pennsylvania.

VALLEJO, F., 1998 - Secuencia Cronológica en Base a la Cerámica Ichimay. In: Resumenes del Primer Coloquio de Arqueología del valle del Rímac durante el Período Intermedio Tardío (12, 13 y 14 de Junio de 1998): 8-11; Lima.

VALLEJO BERRÍOS, F., 2004 - El estilo Ychsma: características generales, secuencia y distribución geográfica. Bulletin de I'Institut Français d'Études Andines, 33 (3): 595642; Número temático «Arqueología de la Costa Central del Perú en los Periodos Tardíos», editado por P. Eeckhout.

VILLACORTA, L. F., 2004 - Los palacios en la Costa Central durante los periodos Tardíos: de Pachacamac al Inca. Bulletin de I'Institut Français d'Études Andines, 33 (3): 539570; Número temático «Arqueología de la Costa Central del Perú en los periodos Tardíos», editado por P. Eeckhout.

ZAMBRANO, R., 2016 - Los Ychsma de Arriba y los Ychsma de Abajo: dos grupos yungas en el valle bajo del río Lurín. Ponencia presentada en el Simposio Señorios Yungas en el Tawantinsuyo; Lima, Perú: Escuela Académico Profesional de Arqueología, UNMSM. 